\title{
On the Ideological and Political Education for College Students in Innovative Ideas
}

\author{
Lina Ma \\ College of Art and Design, Jiangsu Vocational Institute of Commerce, Nanjing 211168, China
}

Keywords: college students, ideological and political education, innovation, personalization, network

\begin{abstract}
In this paper, education innovation in college students' ideological and political science is taken as the independent variable, and "personalized learning" as the dependent variable. Through in-depth interviews with college ideological and political teachers, college students, teaching managers and instructors, this paper conducts qualitative analysis on college students' personalized learning. Based on man's all-round development theory of Marxism, Chinese ancient culture on personalized knowledge learning theory, constructivism learning theory, humanism learning theory and learning theory of multiple intelligences, the theoretical basis of personalized learning, based on the college students' personalized learning in open learning space, personalized learning carrier and course selection form and diversification of learning style of performance, combined with the openness of the college students' individualized learning, initiative, interactivity, situational, humanistic characteristics. This paper conducts systematic analysis on opportunities and challenges in the personalized learning of college students' ideological and political education idea, education mode, education content, education method, faculty, and education evaluation, and then from the college students' ideological and political education innovation, education content, education method, education mode, teaching staff construction, and evaluation mechanism innovation, explores countermeasures for the innovation of ideological and political education from personalized learning horizon.
\end{abstract}

\section{Introduction}

Personalized learning has a long history in China. Confucius first proposed to promote the development of students' personality according to their different characteristics, or to make use of the situation, or to make up for their shortcomings. Individualized learning focuses on cultivating and developing students' creativity, guiding them to learn to compete, to learn to challenge, to learn to surpass their predecessors and selves, to be full of curiosity and spirit of exploration in the scientific field, and to grow into new talents with personality, determination and innovation ability. Individualized learning is an ideal and goal about the development of people's personality, that is, to fully develop and improve the personality of the educated through education. On the practical level, it is a basic requirement for people's education, that is, to take targeted measures according to the personality characteristics of the ducats. In short, education is carried out according to the personality. American psychologists have tracked and studied 800 people for more than 30 years, and found that the main factors of success are non-intelligence factors, among which, confidence, willpower and other personality factors are the primary factors. The research of Chinese psychologists has found that teenagers with normal intelligence have different learning effects due to different personality factors such as emotion, will, personality, motivation and interest. In the actual work of education, it is not hard to find that people with the same level of intelligence do not have the same academic performance, and many personality traits have an important impact on students' academic performance. 


\section{The Status Quo of Ideological and Political Education of College Students}

The strengthening of education in contemporary university students' political thought is a general trend. Only by doing a good job in ideological reform of education can we fundamentally guarantee the establishment of a harmonious socialist society. Due to the development of globalization and the constant influx of external thoughts, the weakening of university students' political thoughts is also obvious while promoting social development. In the face of the complex ideological situation in society, the strengthening of university students' socialist political theory education is the primary problem that needs to be solved at present.

The theories of socialism with Chinese characteristics are summarized into the courses of ideological and political theories of college students, brought into the classroom and sent to the campus. The ideological consciousness in students' minds is constantly strengthened, the understanding of socialism of college students is promoted, and the mastery of socialist theories of college students is helped. Starting from the essence, features and contents of the socialist theory, the socialist ideology of college students is constantly strengthened. The education relationship between political thought and morality is mutually reinforcing and influencing. If it is only unilateral education, it will not achieve the expected effect. If we ignore the relation with moral education in the aspect of ideological education, we cannot guarantee the effect of political ideology education. Therefore, while paying attention to the socialist political thought education, we should pay close attention to the moral basis of education, closely follow the development of socialism, and constantly improve the political thought of college students.

Second, we should strengthen the integrity of college students education. To strengthen the integrity of university education, it is necessary to strengthen the personality building of university students, maintain their healthy physiological and psychological state, and maintain their unremitting pursuit of ideal personality, which is one of the objectives of university students' ideological and political education from the perspective of personalized learning. In the process of ideological and political education content innovation, to constantly adjust the content of ideological and political education, to a modest increase in the attention to current affairs points as well as the correct values guidance, to actively promote the socialist core values, is a college student's sense of honor, know wisely, time that every college students keep the lofty ideal faith, maintain a positive and optimistic attitude towards life.

The traditional virtues of the Chinese nation include integrity and morality. In the development of today's society, one of the basic characteristics of constructing a harmonious society is sincerity and friendship. The harmonious society in which man and nature live in harmony contains such contents as fairness and justice, good faith and friendship, rule of law and so on. These harmonious factors affect the play is to build on the basis of good faith, follow the standard process of morality and the rule of law is the process of abide by integrity, only abide by and respect for the principle of honesty and people activities in order to be able to maintain, make the society full of vigor and the guarantee of law, can better maintain the fair order of society. On the contrary, if the lack of good faith and the rule of law society guarantee, will not be able to guarantee the smooth social order maintenance, inevitable social chaos phenomenon, the interests of the people can't guarantee, fairness and justice cannot be achieved, only in good faith established on the basis of mutual help, honest and good social relations, to promote the establishment of a socialist harmonious society. \& in the process of the implementation of the good faith education, must be closely combining with the characteristics of each college students' personality in order to develop, to improve the individual moral quality of college students, individuals need to guide students to form good habit of thrift, low carbon life, from every university can save water, electricity, don't waste food, consciously choose green travel way, to carry on the rational consumption, reduce life "white trash", consciously put an end to the article "naked" of college students finance lending practices. In a word, the members of the society can only develop harmoniously among the various systems of the society if they establish contacts on the basis of the principle of good faith and morality. In education of contemporary university students' ideological and political thought, honesty and trustworthiness are irreplaceable important content. 
Only when college students have a deep understanding of the importance of being honest and trustworthy can they strengthen the cultivation of their integrity.

Finally, the content of education is also indispensable. Building a harmonious society not only refers to the harmony between people and society, but also includes the harmony between people and nature. Education is an important part of education, which is established in the perspective of harmonious society. Ecological morality refers to the regulation of the relationship between man and nature. It pays attention to cultivating people's ecological moral consciousness, emotion and behavior, instructing people to set up the correct idea of dealing with the harmonious coexistence with nature, and continuously promoting the sustainable development of social production and life. Therefore, it is necessary to strengthen the construction of college students' behavior on the basis of guiding them to establish the concept of ecological morality. The ecological moral quality of college students is inseparable from their behavior habits. To improve their ecological moral level from reality, it is very important to establish good behavior habits. Only by changing bad behavior habits can college students form good behavior habits and meet the requirements of moral development. In daily life, college students should be good at discovering the beauty of nature, paying attention to ecological development and protection, and forming a good habit of protecting the natural environment and natural resources.

\section{Education Innovative Ideas of Ideological and Political Education of College Students}

The network has brought new opportunities and challenges to education and provided the possibility for education method innovation in ideology and politics. The advantages of the Internet such as timeliness, freedom, openness and mutual sharing have provided subjective and objective conditions for the formation of education method in college students' ideological and political affairs. University network ideological and political education can use websites, E-mail, etc. to carry out propaganda and education with ideological and political education information. With the emergence of new network tools, especially the advent of the era of "we media", it has provided a new tool for enhancing the innovation of education. Instant messaging tools such as BBS, blog, QQ and WeChat can effectively enhance the appeal and appeal of education in ideology and politics. Therefore, the technical results obtained in different stages of network development will influence the education method of ideological and political affairs of college students in this period, and the emergence and application of network will diversify the education method of ideological and political affairs.

In recent years, the Internet has been developing rapidly and network technology is becoming more and more mature. As social networks mature, everyone becomes a publisher of information on the Internet. With the rapid improvement of mobile bandwidth, the use of network becomes more and more convenient. With the diverse applications of cloud computing and the Internet of things, the deep application of the Internet has been continuously explored and expanded, and the network has exerted more and more influence on people's lives. In this case, everyone becomes part of the Internet and no one can be isolated from the network environment. There is no denying that the Internet has developed into a new stage, a new stage beyond the previous period.

In the era when big data permeates every industry and business field nowadays, all fields attach great importance to exploring data potential. As a result, education decision-making based on data has gained new development, and has gradually shown its development potential and advantages in the boom of education informatization. With the prominent complexity of problems involved in education decision making and the improvement of the demand for scientific education decision making, the dependence on the power of education data to play with the power of computational ability is becoming stronger and stronger.

On the macro level, big data can provide the education decision-makers with a quantitative, visual, three-dimensional and comprehensive global view, allowing them to fully consider the variables in all aspects. At the same time, decision makers can use computer simulation to calculate big data to get scientific results and avoid blind or even wrong decisions. In the middle view, school and school district management can influence education resource allocation and policy implementation by 
education decision based on data. Data can help schools formulate development plans carefully. At the micro level, the quality of education can be improved by virtue of the quantity, scientific nature and timeliness of big data.

\section{Summary}

With the continuous development of network information technology, the individualized learning of college students has changed from ideal to reality. And personalized learning has a profound impact on college students' world view, values, outlook on life, interpersonal relations, learning and life attitude. Through the analysis of college students' individualized learning, we find that it has both positive and negative effects on university students' ideological and political education. Therefore, the exploration of personalized learning horizon, ideological and political education learning mode, the education idea, education contents and methods of innovation, to discuss the ideological and political education team construction and evaluation mechanism of innovation, the effectiveness of improving the ideological and political education of university students and targeted research value and significance of the self-evident.

Through in-depth interviews, it is learned that although contemporary college students are generally willing to choose personalized learning, their cognition of personalized learning is relatively simple and superficial. Personalized learning is an important way for college students to learn to communicate, collect information and communicate with each other emotionally. Compared with traditional learning methods, personalized learning is more popular and effective for students. But at the same time, personalized learning is also a double-edged sword: on the one hand, it facilitates college students' study and life, and enriches the education teaching mode. On the other hand, it also brings negative effects, that is, it leads to the reduction of self-restraint of students, and the obstacles in interpersonal communication.

\section{References}

[1] Gu Zhaoliang, Gu Fengmiao. On the Class Culture Construction of College Students under the Individualized Learning Environment [J]. Literary and artistic life, 2016,2(2):255-257.

[2] Gu guangliang, gu fengmiao. Challenges and countermeasures of personalized learning on education in college students' ideological and political science [J]. MAO zedong thought research,20I, 6,9(5) 144-148. (In Chinese)

[3] Chen lingjian, li qiong. Exploration and analysis of workflow in college teaching and personalized learning [J]. Beijing: education teaching research,2013(02). (In Chinese)

[4] Liu yong. Exploration and practice of personalized learning support services [J]. Chongqing: chongqing radio and television university, 2013(05). (In Chinese)

[5] Wang jilin. Design and implementation of personalized learning system based on customized services [D]. Hubei: central China normal university, 2014. (In Chinese).

[6] Frozen ping, liu mingyu, gu hua. Practical exploration on the reform of personalized training and teaching from "passive teaching" to "active learning" [J]. Beijing: education teaching BBS, 2014(13). (In Chinese). 